\title{
Agroconsulting as a Tool to Improve the Efficiency of Strategic Planning in the Agricultural Sector
}

\author{
Vitaliy Y. EPANCHINTSEV \\ Ph.D. (in Economics) \\ Omsk State Agrarian University \\ named after P.A. Stolypin \\ 1, Institutskaya Square, Omsk, 644008, Russia \\ Oksana V. SHUMAKOVA \\ Ph.D. (in Economics) \\ Omsk State Agrarian University \\ named after P.A. Stolypin \\ 1, Institutskaya Square, Omsk, 644008, Russia
}

\begin{abstract}
The study examines current issues of consulting support for strategic planning in the agricultural sector in the conditions of digital transformation of agriculture. The hypothesis has been determined and proved: the higher the quality of strategic planning, the higher financial result can be obtained by each enterprise of the agrifood complex, which has included strategic planning in the management process of the enterprise economic service functioning. The content analysis of the main elements of the economic category "Efficiency of strategic planning in agrifood complex" was conducted. Four principal approaches are singled out, the author's definition of this concept is proposed. The positive experience of the Omsk State Agrarian University named after P.A. Stolypin in the part of consulting services to economic entities of agroindustrial complex of the Siberian Federal District in strategic planning is analyzed. Methodological aspects of strategic planning for the purpose of obtaining state support as well as borrowed financing sources were studied. A number of limitations for professional consultants in the process of drawing up investment projects both in form and in its economic content have been determined: the directions of improvement of strategic planning through the formation and development of information and consulting systems taking into account regional factors, which allows to control the implementation of programtargeted objectives and indicative indicators at the state, regional and municipal level, in conditions of intensification of the process of agroindustrial complex digitalization have been defined.
\end{abstract}

Keywords: agroconsulting; efficiency; strategic planning; ACI; content analysis. 


\section{Introduction}

The strategic planning is aimed at ensuring the use of strategic opportunities of economic entities of the agro-industrial complex (hereinafter referred to as "AIC"). At the same time, it should not only not contradict the rational forms of market economy, which provide for the need to take into account the diversity of economic relations in the agrifood market, but also justify the optimal forecast and planned production and (as a consequence) financial indicators (President of Russia, 2018; The Government of the Russian Federation, 2012). The consequence of the Coronavirus Pandemic in 2020 was not only a decline in sales, but also an actual "zeroing" of the function of planning economic activities of many enterprises. Nevertheless, the situation with regard to strategic planning in the agricultural sector remains stable. Federal policy with regard to anti-epidemic measures has suspended (and in some cases irrevocably) quite a large number of sectors of the real economy.

At the same time, the period of self-isolation not only did not reduce the business activity of economic entities of the agrifood complex, but also gave a new impetus to the development of agricultural and processing enterprises in the light of May decisions of the President of the Russian Federation. In this regard, the issues of strategic planning for this sector of economy are more than topical. It is obvious that the higher the quality of strategic planning, the higher the financial result can be obtained by each enterprise of the agrifood complex, which has included strategic planning in the management process of the economic service of the enterprise, along with accounting, financial analysis and internal control. However, not all representatives of agribusiness (legal entities and individuals), especially peasant farms, have economists on staff, who by virtue of their functions are engaged in strategic planning (preparation of development strategy, business plans, feasibility studies).

There is an obvious contradiction. On the one hand, due to production necessity it is necessary to make forecasts and plans, and on the other hand, the enterprises of agro-industrial complex cannot afford to employ an economist, as the costs of his maintenance are considered too high. As a result, even tactical planning is not carried out. There is no production program, no budgets, and often no basic payment calendar. In such a situation, a constructive solution is to apply to agricultural consulting specialists, who deal with strategic planning issues. In this regard, let us consider in more detail agricultural consulting as a tool for improving the efficiency of strategic planning in the agrifood complex. Let us determine that the tool is not a method or type of planning, but an organizational form of making and monitoring the implementation of strategic plans in the agroindustrial complex. 
The purpose of this study is to analyze the mechanism of strategic planning through the functioning of information and consulting systems in the agro-industrial complex and develop constructive proposals to improve its effectiveness.

The following tasks have been solved to achieve the set goal:

1) The analysis of the concept of "efficiency of strategic planning in agro-industrial complex" on the components of "strategic planning" and "efficiency of planning in agro-industrial complex" was conducted;

2) The experience of information and consulting systems functioning in the Omsk State Agrarian University named after P.A. Stolypin (hereinafter referred to as Omsk State Agrarian University) in terms of consulting services to business entities of the agro-industrial complex of the Siberian Federal District in strategic planning was analyzed;

3) The demand for agro-consulting services in strategic planning was monitored among business entities producing and selling agricultural products;

4) A set of measures aimed at developing a mechanism for improving the efficiency of strategic planning in the Omsk Region through agricultural consulting was proposed and justified.

The objects of research are economic entities of the agricultural sector of the Omsk region, which attract specialists in agricultural consulting for the preparation and monitoring of strategic plans. The subject of research - the effectiveness of organizational and economic relations arising between agricultural and processing organizations and the regional infrastructure of agro-consulting in the formation and development of information and consulting systems for strategic planning.

\section{Methods}

Theoretical and methodological basis of the study are the legal acts works of Russian and foreign economists on consulting support of agribusiness, as well as strategic planning of economic activities of agricultural and processing enterprises (Ministry of Agriculture of the Russian Federation, 2017). Through the use of methods of comparative and system analysis, as well as content analysis in the system of strategic planning was studied the functioning of agro-consulting, as one of the effective tools of information and consulting systems in the conditions of digitalization of agricultural sector. The mechanism of increasing the efficiency of organizational and economic relations arising between the subjects of agribusiness and regional infrastructure of agro-consulting in the formation and development of information and consulting systems in the strategic planning part is analyzed. 
The conducted economic research is empirical in nature. The basis for this statement is that the authors have many years of successful experience in the field of agricultural consulting in the Siberian Federal District, including the compilation and monitoring of strategic plans, namely, investment projects of various scales and development strategies. During the period of practical activity the monitoring has been organized and conducted, which allows to perceive, collect and generalize the facts of economic life, which are actually taking place in their real form.

We also analyzed the basic concepts of the subject of study. In particular, strategic planning is essentially determined by the following conceptual apparatus (author's approach):

- substantiation of optimality of forecast and planned production indicators;

- actions on development of specific strategies of the enterprise, focused on the achievement of goals, a real possibility of optimization of the mechanism of state support.

- the process of goal setting based on the ratio of the external environment to the availability of resources;

- complex system of perspectives of development of branches for further effective existence, view from the future to the present;

- a process that can be implemented with the necessary information and relevant competences;

- ensuring the implementation of mega-projects on the basis of alternative project monitoring and risk management;

- process chain planning: production - processing - sales of finished products;

Thus, the process of increasing the efficiency of strategic planning in the agrifood complex in conditions when it is carried out through information and consulting systems with the involvement of external specialists in agricultural consulting was studied.

\section{Review of literature}

Researches in a part of a scientific and methodological component of formation and development of information and consulting systems were actively conducted by foreign scientists: Jones, Sharma, Muellerij, Birner, Davis, Pender, Nettle, Crawford, Brightling. At the same time, considerable attention is paid to business development in essence, taking into account the basic principles of trade facilitation, long-term growth of small businesses and entrepreneurial risk (Vesković, 2014; Willer, Minou, 2007; Wu, 2008). This topic has also been studied by Russian scientists, including in the sphere of strategic planning. The author's definitions of the term "planning efficiency" have been analyzed, and four principal approaches have been singled out: classical (achievement of 
indicators), feasibility of calculations, by planning objectives, and management approach. In most cases, planning efficiency is expressed by the achievement of socio-economic, production and/or environmental indicators. The advantages of this approach are accessibility, universality and quantitative measurability, but aspects of agricultural enterprise management are not considered.

In the second approach, planning is considered effective if certain indicators are reasonably calculated. Such approach has advantages in legal aspect, but does not take into account possible changes in the period of the strategic plan implementation. The authors of the concept of the third approach consider planning effective if it was possible to achieve the set goals or to create economic bases for realization of the goals. The given approach allows to understand accurately, how effective planning is, but in most cases has a low level of detail in space and in time.

Within the limits of the administrative approach planning which provides timely preparation of the administrative information, promotes the decision of administrative problems and provides working out of the program of development is considered effective. Its advantage is that it takes into account not only the economic side of planning, but also the managerial one. On the other hand, in the real activities of a business entity, strategic management decisions require constant adjustment taking into account constantly changing circumstances, which is one of the weaknesses of this approach.

Content characteristics revealed as a result of the analysis of the conceptual apparatus of strategic planning, presented in Table 1, allow to reveal the main elements of the concept "efficiency of strategic planning in agro-industrial complex" by the method of content analysis.

Table 1. Description of the content of the concept of "planning efficiency" in the ongoing

\section{review of literature}

\begin{tabular}{|c|c|c|}
\hline Author & Author's approach & The essence of the concept \\
\hline Reshetnikova & $\begin{array}{l}\text { Classic approach (indicator } \\
\text { achievements) }\end{array}$ & $\begin{array}{l}\text { Achievement of indicators of necessary } \\
\text { volumes of food commodity supply and the } \\
\text { size of solvent demand of population } \\
\text { (Reshetnikova, 2016). }\end{array}$ \\
\hline Palatkin, Czech & $\begin{array}{c}\text { Approach to feasibility of strategic plan } \\
\text { calculations }\end{array}$ & $\begin{array}{l}\text { Justified calculation of indicators of working } \\
\text { capital demand for a pessimistic market } \\
\text { situation (Palatkin, Czech, 2015). }\end{array}$ \\
\hline Litchko & $\begin{array}{c}\text { Classic approach (indicator } \\
\text { achievements) }\end{array}$ & $\begin{array}{l}\text { Achievement of socio-economic indicators } \\
\text { (Romaniuk, Litchko, 2015). }\end{array}$ \\
\hline Egorova & $\begin{array}{c}\text { Targeted approach (by planning } \\
\text { objectives) }\end{array}$ & $\begin{array}{l}\text { Creation of economic basis for realization of } \\
\text { strategic goals of business processes of } \\
\text { economic subject (Egorova, 2016). }\end{array}$ \\
\hline Lysochenko & $\begin{array}{c}\text { Classic approach (indicator } \\
\text { achievements) }\end{array}$ & $\begin{array}{l}\text { Achievement of production, socio-economic } \\
\text { indicators (Lysochenko, 2016). }\end{array}$ \\
\hline Rudoy & $\begin{array}{l}\text { Classic approach (indicator } \\
\text { achievements) }\end{array}$ & $\begin{array}{l}\text { Achievement of economic indicators (Rudoy, } \\
\text { Afanas'ev, Silina, 2010). }\end{array}$ \\
\hline $\begin{array}{l}\text { Svyatova, } \\
\text { Soloshenko. }\end{array}$ & Management approach & $\begin{array}{l}\text { Efficient Solution of Management Problems } \\
\text { (Svyatova, Ziukin, Soloshenko, Dorogavtseva, } \\
\text { 2017). }\end{array}$ \\
\hline Baryshnikov & Classic approach (indicator & Achievement of indicators to reduce \\
\hline
\end{tabular}




\begin{tabular}{|c|c|c|}
\hline & achievements) & $\begin{array}{l}\text { dependence on food imports (Baryshnikov, } \\
\text { Samygin, 2016). }\end{array}$ \\
\hline Doholyan & Management approach & $\begin{array}{l}\text { Ensuring timely preparation of management } \\
\text { information (Dokholyan, Ibragimova, 2011). }\end{array}$ \\
\hline $\begin{array}{l}\text { Chernova, } \\
\text { Mitrofanova. }\end{array}$ & $\begin{array}{l}\text { Classic approach (indicator } \\
\text { achievements) }\end{array}$ & $\begin{array}{l}\text { Ensuring the fulfillment of indicators of } \\
\text { restoration and modernization of agriculture } \\
\text { (Chernova, Mitrofanova, 2017). }\end{array}$ \\
\hline $\begin{array}{l}\text { Maidanevich, } \\
\text { Anopchenko. }\end{array}$ & $\begin{array}{l}\text { Classic approach (indicator } \\
\text { achievements) }\end{array}$ & $\begin{array}{l}\text { Achievement of economic and ecological } \\
\text { efficiency indicators } \\
\text { Anopchenko, 2017). }\end{array}$ \\
\hline Semin, Mikhailuk & $\begin{array}{l}\text { Classic approach (indicator } \\
\text { achievements) }\end{array}$ & $\begin{array}{l}\text { Achievement of economic and social } \\
\text { efficiency indicators (Semin, Mikhailiuk, } \\
\text { 2012). }\end{array}$ \\
\hline Chepik, Chepik & $\begin{array}{c}\text { Classic approach (indicator } \\
\text { achievements) }\end{array}$ & $\begin{array}{l}\text { Achievement of strategic plan indicators } \\
\text { (Chepik, Chepik, 2014). }\end{array}$ \\
\hline $\begin{array}{l}\text { Zavodchikov, } \\
\text { Voronkova }\end{array}$ & $\begin{array}{l}\text { Classic approach (indicator } \\
\text { achievements) }\end{array}$ & $\begin{array}{l}\text { Achievement of energy saving and investment } \\
\text { efficiency indicators (Zavodchikov, } \\
\text { Voronkova, 2010). }\end{array}$ \\
\hline Kolyvanov & Management approach & $\begin{array}{l}\text { Ensuring that the development agenda is } \\
\text { formulated according to the strategies adopted } \\
\text { (Ibragimova, Kolyvanov, 2012). }\end{array}$ \\
\hline
\end{tabular}

In the considered approaches there are disadvantages in the disclosure of the essence of the concept under study, therefore, the author's definitions studied require adjustment taking into account the economic, technological and legal components.

With all the variety of sources and formulations used, there is an objective reality of duplication of the main structural elements of this concept. The obtained data on the frequency of references to the object definitions can be arranged in descending order from more to less. The rating of the most frequently met main elements of the concept "efficiency of strategic planning in the agro-industrial complex" is as follows: indicator - 23 , achievement -21 , economic -10 , production -5 , social -4 , target - 4, provision - 3, justification - 3, calculation - 3, strategic plan - 3, productivity - 2, resources -2 , management -2 , environmental -2 , recovery -1 , profitability -1 .

The information base of the research was provided by data of federal executive authorities, results of research works, as well as consulting products of FSBEI of Higher Education Omsk SAU.

\section{Results}

The logical analysis of the concept of "planning efficiency" on the basis of an accurate explanation of their content and structure allowed to determine the ratio of constituent elements and to make a holistic view of the state of the phenomenon under study. The structure of logical analysis of basic concepts consists of the definition of planning efficiency as the achievement of target indicators; achievement of production, socio-economic indicators; effective solution of management problems. 
The data obtained as a result of the content analysis of the notion "efficiency of strategic planning in agro-industrial complex" show that in general, the positions of the authors testify to the complex approach in determining the totality of basic elements of this notion. A retrospective analysis of the concept of "agro-industrial complex" was carried out to identify logical relationships. Thus, for the purpose of revealing of the basic characteristics of elements the author's content analysis of a category "efficiency of strategic planning in agrarian and industrial complex" presented in the Table 2 was carried out.

The economic and production components of the effectiveness of strategic planning in the agrifood complex are the subject of continuous research by scientists. The quality of strategic planning of economic activity of agricultural and processing enterprises depends not only on the provision of expanded capital reproduction, but also on the sustainable development of rural areas.

\section{Table 2. Author's content analysis of the category "efficiency of strategic planning in the \\ agricultural sector"}

\begin{tabular}{|c|c|c|}
\hline $\begin{array}{l}\text { The effectiveness of strategic } \\
\text { planning in agriculture is }\end{array}$ & $\begin{array}{l}\text { Efficiency of planning, strategy, } \\
\text { agro-industrial complex (content } \\
\text { analysis) }\end{array}$ & $\begin{array}{l}\text { Content of the definition in } \\
\text { substance }\end{array}$ \\
\hline $\begin{array}{c}\text { the system of performance } \\
\text { indicators of the strategic plan } \\
\text { implementation... }\end{array}$ & Interpretations by scientists & $\begin{array}{c}\text { Indicator - Purpose - Security - } \\
\text { Presence }\end{array}$ \\
\hline ...a business entity... & Legal status & $\begin{array}{l}\text { PJSC; JSC; OOO; peasant farms; } \\
\text { SEC; individual entrepreneurs; } \\
\text { personal subsidiary economy }\end{array}$ \\
\hline ... AIC... & AIC sectors & $\begin{array}{l}\text { Production of means of } \\
\text { production; agriculture; processing } \\
\text { of agricultural raw materials; } \\
\text { agricultural infrastructure }\end{array}$ \\
\hline $\begin{array}{l}\text {...which is expressed in the } \\
\text { achievement of legal... }\end{array}$ & Legal relations & $\begin{array}{l}\text { Compliance of the strategy with } \\
\text { regulations: Federal, regional, } \\
\text { local, local }\end{array}$ \\
\hline ...target values... & Indices & $\begin{array}{l}\text { Level of profitability, profit, sales } \\
\text { revenue, production volume, } \\
\text { amount of investments, budget } \\
\text { effect, number of jobs created }\end{array}$ \\
\hline ...in a given period of time... & Time & $\begin{array}{c}\text { Planning horizon } \\
\text { Plan implementation period }\end{array}$ \\
\hline $\begin{array}{l}\text {...taking into account sustainable } \\
\text { rural development... }\end{array}$ & Space & $\begin{array}{l}\text { Sustainable development of rural } \\
\text { areas is a process of changing } \\
\text { various spheres of life in the rural } \\
\text { community (social, economic, } \\
\text { environmental sphere). }\end{array}$ \\
\hline ....and enhanced reproduction... & Capital & $\begin{array}{l}\text { Extended Reproduction is the re- } \\
\text { creation of used factors of } \\
\text { production at an increased scale }\end{array}$ \\
\hline $\begin{array}{l}\text {...through the effective use of } \\
\text { factors of production. }\end{array}$ & Resources & $\begin{array}{l}\text { Land, capital, labor, } \\
\text { entrepreneurial skills, information }\end{array}$ \\
\hline
\end{tabular}


The analysis of different approaches to the definition of "efficiency of strategic planning in the agro-industrial complex" allowed us to formulate its author's definition. The efficiency of strategic planning in the agro-industrial complex is understood as a system of performance indicators of realization of the strategic plan of an economic entity of the agro-industrial complex, which is expressed in achievement of legally formalized target values in the set period of time taking into account provision of sustainable development of rural territories and expanded reproduction due to effective use of production factors.

The effectiveness of strategic planning in the agro-industrial complex depends on the organizational and legal form of the planning object, the specific sphere of agro-industrial complex, legal relations in the process of plan implementation, the percentage of implementation of planned economic indicators in time and space, the level of reproduction of fixed capital with available or limited in various degrees resources.

Due to the fact that efficiency is a complex economic indicator covering all areas of agriculture, the quantitative expression of its evaluation is quite diverse. A large number of economic, technical, technological and legal criteria, attraction of all available resources of planning subjects do not allow to estimate efficiency by one indicator. Currently, a holistic system of indicators is used for this purpose.

We believe that in order to determine the effectiveness of strategic planning in the agro-industrial complex it is necessary to form a system of indicators for a comprehensive and objective analysis, as it allows to assess the quality of planning not only from the economic and managerial point of view, but also from the legal point of view, which allows to achieve a synergistic effect in the chain: planning - accounting - analysis - control.

Summarizing the results and summarizing the above research, it should be concluded that in the current economic situation there are many terminological phrases with a single basis of "strategy effectiveness": "planning efficiency", "forecasting efficiency". Many scientists-economists, applying the given concepts in the scientific works, frequently put in them uniform sense. In our interpretation and as object of our research the resulted above word-combinations act as the synonymous concepts bearing uniform semantic loading. Practical definition of efficiency of strategic planning in agrarian and industrial complex is carried out by its quantitative and qualitative estimation including data on properties of object of planning.

\section{Discussion}

In Omsk State Agrarian University named after P.A. Stolypin (hereinafter referred to as Omsk State Agrarian University) since 2017 information and consulting assistance to the real sector of economy 
in terms of strategic planning has become more active (Vizgalev, 2019). The main customers of consulting services are economic entities of the agroindustrial complex (hereinafter referred to as "AIC") of the Siberian Federal District. At the same time, more than 85 percent of the total volume of economic consulting is made up of business plan preparation services (the authors are heads of project teams for the absolute majority of investment projects). In particular, between 2017 and 2019 inclusive, 16 such projects were prepared with a total amount of financing of 6.34 billion rubles, including 81.2 million rubles of state support. These analytical data are presented in Table 3.

Table 3. Investment projects prepared by Omsk SAU in 2017 - 2019 within the framework of information and consulting assistance to business entities of agricultural sector

\begin{tabular}{ccccc} 
AIC sectors & $\begin{array}{c}\text { Number of } \\
\text { projects }\end{array}$ & $\begin{array}{c}\text { Investments, } \\
\text { million rubles }\end{array}$ & $\begin{array}{c}\text { Geography of } \\
\text { projects }\end{array}$ & State support, million rubles \\
\hline Plant production & 2 & 2133.2 & $\begin{array}{c}\text { the Russian } \\
\text { Federation (Omsk } \\
\text { region. Novosibirsk } \\
\text { region). PRC }\end{array}$ & 20.0 \\
\hline $\begin{array}{l}\text { Farm animal } \\
\text { production }\end{array}$ & 10 & 341.4 & Omsk region & 33.6 \\
\hline Food industry & 4 & 3864.5 & $\begin{array}{c}\text { Federation (Omsk } \\
\text { region. Novosibirsk } \\
\text { region). PRC }\end{array}$ & 27.6 \\
\hline Total & 16 & X
\end{tabular}

The analysis of the projects themselves, as well as the impact of their implementation on the gross regional product, is a separate volume topic that requires independent research. Therefore, let us focus on the methodological aspects of strategic planning in order to obtain government support, as well as borrowed funding from a commercial bank (Rosselkhozbank JSC). In particular, for professional advisors in drawing up long-term plans and forecasts by the regional executive authorities a priori a number of restrictions are imposed both on the form of an investment project and its economic content:

1) the business plan provides for an annual increase in production and sales of $10 \%$ of the previous year;

2) profitability is considered with the grant funds in the profitable part of the project, i.e. profitability without the grant is not considered ;

3) property, plant and equipment are written off at the beginning of the project period, no depreciation is charged on them;

4) receipt of the loan is reflected in the income part, repayment of borrowed funds - in the expenditure part of the project; 
5) when calculating the payback period, the first year of receiving a grant is considered the full calendar year, regardless of the number of months. For example, when receiving a grant in October 2019 - 2.5 months of 2019 are considered as 12 months;

6) planning horizon - payback period of the project plus 1 year;

7) profit is considered to be the difference between the revenue and expenses taking into account paragraphs 2,3 and 4 ;

9) profitability is defined as the ratio of profit to expenses taking into account paragraphs 2,3 and 4;

10) cash flows are not separately reflected in the business plan.

In turn, the requirements of the commercial bank to the investment project are different, in many respects contrary to the format of the regional Ministry of Agriculture. At submission of the business plan the bank requests the information preparation of which assumes high level of qualification of the executor (risk estimation, estimation of economic efficiency, detailed analysis of the sales market), in this connection the producer of agricultural production, as a rule, addresses to the adviser. There are issues that agricultural consulting organizations (including the Omsk State Agrarian University) have yet to resolve. Let us consider the main contradictions .

1. The bank's recommendations on strategic planning do not include a tabular form of information presentation. At the same time, the Ministry has prepared ready-made table forms to be filled in. The commercial bank is not satisfied with this project form.

2. The probability of objective reflection of the risks mentioned in the recommendations (as required by the bank) when drawing up a business plan to receive state support is close to zero. Grant recipients will indicate natural and climatic risks and increased tax burden.

3. The labor intensity of preparing a business plan based on the recommendations proposed by the bank regarding the format of the business plan of the Ministry of Agriculture and Food of the Omsk Region is increasing with a factor greater than twofold.

4. Due to the circumstances indicated in the previous contradiction, the cost of drawing up a business plan on the proposed recommendations will be 30 - 50 thousand rubles. While currently farmers order business plans in the consulting market at the price of 10 - 20 thousand rubles per unit.

Thus, the directions of improvement of strategic planning through the formation and development of information and consulting systems taking into account regional factors (typical for the absolute 
majority of the subjects of the Siberian Federal District) at the meso-, micro- and mini-level of management in the system of agrofood complex, which allows to control the implementation of program-targeting units and indicative indicators at the state, regional and municipal levels, in conditions of activation of the process of digitalization.

\section{Conclusion}

Theoretical importance of this study is to clarify the content of the category "efficiency of strategic planning in the agro-industrial complex"; to develop the methodology of strategic planning in the situation of attracting information and consulting systems. The practical importance is determined by the development of a set of measures aimed at developing a mechanism to improve the efficiency of strategic planning in the Omsk region through agricultural consulting, which are presented below.

1. Agricultural consulting services in strategic planning are most demanded by small and medium-sized businesses in the agricultural sector.

2. A high level of strategic planning efficiency in a situation where the plan developer is an agricultural consulting company can be achieved only with further monitoring of the plan (project) implementation by agricultural consulting specialists throughout the planning horizon.

3. In the process of developing and monitoring the strategic plan, not only specialists in economic planning (business planning, economics, finance), but also specialists in agricultural production and processing technology (agronomists, zootechnicians, technologists, etc.) should participate.

4. When developing a strategic plan, specialists in agricultural consulting should take into account financial and legal implications of the implementation of key planning indicators, taking into account available resources and constraints within the legal framework.

5. Since the qualitative development of the strategic plan requires a high level of qualification of executors, agricultural consulting companies need not only to select in time, but also to train personnel, taking into account the level of responsibility of specialists in agricultural consulting and the level of competition in terms of employers' demand for highly skilled labor in the market of consulting services.

Thus, the solution of the set of the outlined problems is important for defining the perspective directions of the development of the agrifood complex. As a result, it contributes to ensuring food security through the production of competitive Russian products of high processing depth in response to the threats of global challenges in foreign and domestic markets through the mass 
IV International Scientific and Practical Conference "Modern S\&T Equipments and Problems in Agriculture"

introduction of complex digital agricultural solutions, mass acquisition of digital competencies by specialists of agricultural enterprises.

\section{Acknowledgments}

This research was conducted with the financial support of the Omsk State Agrarian University named after P.A. Stolypin.

\section{References}

Baryshnikov, N.G., Samygin, D.Y. (2016). Strategic development of agrarian sector: regional experience and forecasts. Volga Region Farmland, 3(40), 112-121.

Chepik, S.G., Chepik, O.V. (2014). Efficiency of the strategic planning and forecasting of the production and financial activity of the agricultural commodity producers at the regional level. Accounting and statistics, 1(33), 64-68.

Chernova, O.A., Mitrofanova I.V. (2017), The role of agroindustrial clusters in formation of growth areas of an economic complex of the south of Russia. Economy: yesterday, today, tomorrow, 7(3B), 326-338.

Dokholyan, S.V., Ibragimova, Z.A. (2011). Organizational aspects of the strategic planning process at the AIC processing enterprise. Regional problems of the economy transformation, 2, $235-248$

Egorova, E.M. (2016). Budgeting in the economic subjects of agroindustrial complex: development of organizational-methodological bases. Journal of Nizhnevolzhsk Agrouniversity Complex: Science and higher professional education, 1(41), 269-275.

Evaluation of the Implementation of the Farm Advisory System. Retrieved from: https://ec.europa.eu/ag-riculture/evaluation/market-and-income-reports/2009-fas_en (Accessed on May 4, 2020).

Final Report Summary - PRO AKIS (Prospects for Farmers' Support: Advisory Services in European AKIS). Retrieved from: https://cordis.europa.eu/project/rcn/105025/reporting/en (Accessed on May 5, 2020).

Ibragimova, Z.A., Kolyvanov, V.Y. (2012). Organizational and functional model of the strategic planning at the enterprises of AIC. Regional problems of economy transformation, 1, 206-215. 
IV International Scientific and Practical Conference "Modern S\&T Equipments and Problems in Agriculture"

Lysochenko A.A. (2016). Regional strategy and problems of AIC development. Strategy of sustainable development of Russian regions, 30, 106-113.

Maidanevich, Y.P., Anopchenko, T.Y. (2017). Strategy of the AIC development in the context of the region steady development. Science and education: economy and economy; business; law and management, 6(85), 26-33.

Ministry of Agriculture of the Russian Federation. (2017). The Order of the Ministry of Agriculture of the Russian Federation of 12 January, 2017 No. 3 «On approval of the forecast of scientific and technological development of AIC of the Russian Federation for the period up to 2030». Retrieved from: https://base.garant.ru/71599570/ (Accessed on May 10, 2020).

Palatkin, I.V., Czech, K.Y. (2015). Analysis of the institutional basis of the strategic plans of the Penza region AIC development. Theoretical and applied aspects of modern science, 8-6, 162-165.

President of Russia. (2018). The Edict of the President of the Russian Federation of 7 May, 2018 "On national development goals and strategic objectives of the Russian Federation for the period up to 2024". Retrieved from: http://kremlin.ru/events/president/news/57425 (Accessed on May 12, 2020).

Reshetnikova, E.G. (2016). Areas of improvement of the AIC development strategic planning. New science: Theoretical and practical view, 5-1(81), 218-220.

Romaniuk, M.A., Litchko, K.P. (2015). About the strategic planning in the Russian Federation. Journal of Timiryazev Agricultural Academy, 6, 83-91.

Rudoy, E.V., Afanas'ev, E.V., Silina, L.V. (2010). Theoretical aspects of the strategy of AIC development. Bulletin of the Altai State Agrarian University, 1(63), 79-82.

Semin, A.N., Mikhailiuk, O.N. (2012). Forms and priorities of the state support of the domestic agricultural commodity producers. Agrofood policy of Russia, 6, 5-11.

Svyatova, O.V., Ziukin, D.A., Soloshenko, R.V., Dorogavtseva, I.G. (2017). Development of the strategic guidelines for the balanced development of the Russian sugar beet subcomplex. Bulletin of the Kursk State Agricultural Academy, 3, 71-74.

Target groups and main methods of advisory services in surveyed EU countries. Final Report Summary - PRO AKIS (Prospects for Farmers' Support: Advisory Services in European AKIS)/ Retrieved from: https://cordis.europa.eu/project/rcn/105025/reporting/en. (Accessed on May 10, 2020). 
IV International Scientific and Practical Conference "Modern S\&T Equipments and Problems in Agriculture"

The European Cloud initiative. from:

https://ec.europa.eu/digital-smgle-market/en/\%20euro-pean-cloud-initiative.

(Accessed on May 10, 2020).

The Government of the Russian Federation. (2012).The government program of agricultural development and regulation of agricultural products, raw materials and food markets in 2013 - 2020. Approved by Enactment of the Government of the Russian Federation of 14 July, 2012 No. 717. Retrieved from: http://government.ru/programs/208/events/ (Accessed on May 12, 2020).

University of Arkansas System. Division of Agriculture. Cooperative Extension Service. Retrieved from: https://www.uaex.edu/default.aspx. (Accessed on May 12, 2020).

Vesković, N. (2014). Aspects of entrepreneurial risk. Finiz Singidunum University International Scientific Conference, 115-117.

Vizgalev, A. (2019). Agro startups of the business incubator of Omsk State Agrarian University received grant support for the development of animal husbandry. FSBEI of Higher Education «Omsk State Agrarian University named after P.A. Stolypin». (2019). Retrieved from: $\quad$ https://www.omgau.ru/inc/novosti/agrostartapy-biznes-inkubatora-omskogo-gaupoluchili-grantovuyu-podderzhku-na-razvitie-zhivotnovodst/. (Accessed on May 12, 2020).

Willer, H., Minou, Y. (2007). The World of Organic Agriculture. Statistics and Emerging Trends. Germany: IFOAM.

Wu, J. (2008). An Empirical Evidence of Small Business Financing in China. Management Research News, 31(12), 959-975.

Zavodchikov, N.D., Voronkova, E.A. (2010). Energy budget of the Orenburg region in view of the agricultural production development. Regional economics: theory and practice, 2, 12-16. 